\title{
Penerapan Model Pembelajaran Kooperatif Tipe STAD untuk Meningkatkan Hasil Belajar Matematika pada Siswa Kelas V SDI Blidit Kabupaten Sikka
}

\author{
Theresia Anisensia ${ }^{1 *}$, Gregorius Sebo Bito ${ }^{2}$, Marselina Wali ${ }^{3}$ \\ 1,2,3 Program Studi PGSD Universitas Flores Ende. \\ Jalan Samratulangi, Kelurahan Pupire, Ende, Flores, Indonesia \\ * Corresponding Author: anisensiatheresia@gmail.com
}

\section{Info Artikel Abstract}

Sejarah Artikel:

Diterima 11/03/2020

Direvisi 17/03/2020

Disetujui 19/03/2020

Keywords: Model Learning Kooperatif STAD type, Student Learning Outcomes.
The objectives of this study are: 1) to know the implementation of cooperative learning model of STAD type in mathematics learning in class V students in SDI Blidit, Waigete, Sikka Regency, 2) to find out the improvement of students' learning outcomes after applying cooperative learning model of STAD type on mathematics learning in class V students in SDI Blidit, Waigete, Sikka Regency. This research is a type of Classroom Action Research (CAR) by using a qualitative approach. The subject in this study was the V-grade SDI Blidit student, numbering 20 students. The techniques of data collection in this study were observation, interview, test and documentation. Based on the results of the data analysis and the discussion of the results can be concluded that the results of the study of class $V$ students in mathematics after implementation the cooperative learning model of STAD type in cycle I has not reached the complete learning. It can be seen from the number of students who reached the KKM or minimal completeness criteria is 6 people (60.5\%) of 20 students, while in cycle II has undergone an increase by an overall percentage of $86 \%$. Teacher and student activities also increased from cycle I to cycle II; $(56.15 \%)$ in cycle I and (84.61\%) in cycle II with its criteria is very good. While the student activity cycle I (50\%) and cycle II (87.7\%) are in excellent criteria. Based on the results of the interviews, it can be concluded that students are motivated when learning materials are implemented using the STAD type Cooperative learning model.

\begin{abstract}
Abstrak
Tujuan penelitian ini adalah: 1) untuk mengetahui penerapan model pembelajaran kooperatif tipe STAD pada pembelajaran matematika pada siswa kelas V SDI Blidit Kecamatan Waigete, Kabupaten Sikka, 2) untuk mengetahui peningkatan hasil belajar siswa setelah diterapkan model pembelajaran kooperatif tipe STAD pada pembelajaran matematika di kelas V SDI Blidit Kecamatan Waigete, Kabupaten Sikka. Penelitian ini merupakan jenis penelitian tindakan kelas (PTK) dengan menggunakan pendekatan kualitatif. Subjek dalam penelitian ini adalah siswa kelas V SDI Blidit yang berjumlah 20 orang. Teknik pengumpulan data yang digunakan dalam penelitian ini adalah observasi, wawancara, tes dan dokumentasi. Berdasarkan hasil analisis data dan pembahasan hasil penelitian dapat disimpulkan bahwa hasil belajar siswa kelas V pada pelajaran Matematika setelah diterapkan model pembelajaran kooperatif tipe STAD pada siklus I belum mencapai ketuntasan belajar. Hal ini terlihat dari jumlah siswa yang mencapai KKM adalah 6 orang $(60,5 \%)$ dari total 20 siswa, sedangkan pada siklus II sudah mengalami peningkatan dengan presentase keseluruhan $86 \%$. Aktivitas guru dan siswa juga meningkat dari siklus I ke siklus II; $(56,15 \%)$ di siklus I dan $(84,61 \%)$ di siklus II dengan kriterianya sangat baik. Sedangkan aktivitas siswa pada siklus I (50\%) dan siklus II $(87,7 \%)$; berada pada kriteria sangat baik. Berdasarkan hasil wawancara dapat disimpulkan bahwa siswa merasa termotivasi apabila materi pembelajaran diterapkan oleh guru dengan menggunakan model pembelajaran Kooperatif tipe STAD.
\end{abstract}

\footnotetext{
*Alamat korespondensi:

Program Studi Pendidikan Guru Sekolah Dasar

Fakultas Keguruan dan Ilmu Pendidikan Universitas Flores

Kampus III Universitas Flores, Jln. Samratulangi,

Kelurahan Paupire, Ende, NTT

E-mail: anisensiatheresia@gmail.com
}

() 2020 Program Studi PGSD Universitas Flores Email: primagistrauniflor@gmail.com 
Theresia Anisensia, Gregorius Sebo Bito dan Marselina Wali

Penerapan Model Pembelajaran Kooperatif Tipe STAD untuk Meningkatkan Hasil Belajar Matematika pada Siswa Kelas V SDI Blidit Kabupaten Sikka

PRIMA MAGISTRA: Jurnal Ilmiah Kependidikan Nomor 1, Volume 1, April 2020, hal 61-69

\section{PENDAHULUAN}

Matematika adalah suatu ilmu tentang informasi yang diperoleh dari kegiatan pengolahan suatu data yang dapat memberikan gambaran tentang suatu keadaan atau masalah, baik yang berupa angka-angka (golongan) maupun yang berbentuk kategori dari suatu kegiatan atau suatu peristiwa. Matematika sangat diperlukan baik untuk kehidupan sehari-hari maupun dalam kemajuan IPTEK sehingga matematika perlu dibekalkan kepada setiap siswa. Matematika pada hakekatnya merupakan suatu ilmu yang cara bernalarnya deduktif formal dan abstrak, harus diberikan kepada anak-anak sejak SD yang cara berpikirnya masih pada tahap operasional konkret (Hudojo, 2005: 37).

Pembelajaran matematika adalah proses yang dirancang dengan tujuan menciptakan suasana lingkungan yang memungkinkan seseorang melaksanakan kegiatan belajar matematika, dan berpusat pada guru yang mengajar matematika dan melibatkan siswa. Pembelajaran matematika harus memberi peluang pada siswa untuk berusaha dan mencari tahu tentang matematika. Program pembelajaran matematika harus berjalan sesuai rencana. Bila dalam perjalanan menemui kendala, halangan dan kurangnya fasilitas yang menunjang, maka harus ada upaya pengembangan terlebih dahulu (Hamzah dkk, 2014: 65).

Salah satu masalah yang dihadapi dunia pendidikan kita adalah masalah lemahnya proses pembelajaran. Dalam proses pembelajaran, anak kurang didorong untuk mengembangkan kemampuan berpikir. Proses pembelajaran di dalam kelas diarahkan kepada kemampuan anak untuk menghafal informasi, otak anak dipaksa untuk mengingat dan menimbun berbagai informasi tanpa dituntut untuk memahami informasi yang diingatnya terutama pada mata pelajaran matematika. Mata pelajaran matematika bertujuan agar siswa mampu untuk memecahkan masalah, menyelesaikan, dan menafsirkan solusi yang diperoleh.

Berdasarkan pengamatan yang dilakukan di SDI Blidit pada siswa kelas V hasil belajar tergolong masih rendah dan belum mencapai Kriteria Ketuntasan Minimal (KKM) 65 hal ini dibuktikan pada awal sebelum memakai model pembelajaran kooperatif tipe STAD dengan pemberian pree test dari 20 siswa yang tuntas hanya 2 siswa dan yang belum tuntas 18 siswa khususnya pada pembelajaran matematika. Kurangnya pembelajaran matematika dipengaruhi oleh berbagai faktor, faktor tersebut seperti kemampuan belajar siswa masih kurang, dan pada saat pembelajaran ada siswa yang mendengarkan guru dengan baik ada siswa yang sibuk bermain dengan teman sebangkunya dan tidak memperhatikan guru di depan kelas, dan ketika diberikan diskusi soal hanya siswa tertentu saja yang aktif, dan model pembelajaran kurang sesuai dengan materi yang diberikan, serta masih kurang guru dalam bidang matematika. Permasalahan tersebut disebabkan karena penggunaan model pembelajaran di kelas kurang menarik atau efektif sehingga membuat siswa merasa jenuh, bosan dan sibuk bermain dengan teman sebangkunya. Hal ini dapat menyebabkan hasil belajar siswa pada mata pelajaran matematika menurun atau rendah.

Dalam rangka mengatasi masalah di atas, guru harus mampu menerapkan konsepkonsep dasar pembelajaran untuk mempelajari matematika, sehingga matematika dapat menjadi bagian dari kehidupan siswa dan tidak menerima begitu saja apa yang dipelajari, menghafal rumus dan prosedur penyelesaian yang diberikan tetapi dengan membangun makna dari apa yang dipelajari dengan pemahaman akan unsur-unsur yang terdapat didalamnya dan guru harus mampu memilih atau menerapkan model pembelajaran yang sesuai dengan masalah yang dihadapi oleh siswa, agar siswa lebih aktif dalam proses pembelajaran. Salah satu solusi yang dapat digunakan oleh guru agar siswa lebih aktif dalam proses pembelajaran yaitu dengan menggunakan model pembelajaran kooperatif.

Model pembelajaran kooperatif tipe STAD merupakan salah satu model yang paling sederhana yang menekankan pada aktivitas dan interaksi diantara siswa untuk saling mendukung dan membantu satu sama lain dalam memahami suatu materi pelajaran yang diajarkan oleh guru (Hamzah,dkk, 2014: 163). Pembelajaran ini berlangsung di mana guru tidak mendominasi kegiatan pembelajaran tetapi pembelajaran didominasi 
Theresia Anisensia, Gregorius Sebo Bito dan Marselina Wali

Penerapan Model Pembelajaran Kooperatif Tipe STAD untuk Meningkatkan Hasil Belajar Matematika pada Siswa Kelas V SDI Blidit Kabupaten Sikka

PRIMA MAGISTRA: Jurnal Ilmiah Kependidikan Nomor 1, Volume 1, April 2020, hal 61-69

oleh siswa. Guru menjadi fasilitator pada proses pembelajaran tersebut, dan yang berperan aktif dalam pembelajaran adalah siswa. Inti dari STAD adalah guru menyampaikan materi, kemudian para siswa bergabung dalam kelompok untuk menyelesaikan soal-soal yang diberikan oleh guru.

\section{METODE PENELITIAN}

Rancangan penelitian yang digunakan dalam penelitian ini adalah Penelitian Tindakan Kelas. Penelitian ini di dasarkan pada jenis masalah yang diangkat oleh peneliti tentang masalah-masalah yang terjadi dalam kelas yang bertujuan untuk memecahkan masalah atau meningkatkan mutu pembelajaran di kelas tersebut.

Penelitian ini dilaksanakan di SDI Blidit, pada mata pelajaran Matematika. Penelitian ini dilaksanakan kurang lebih dua minggu, dari tanggal 20 Mei sampai dengan tanggal 2 Juni 2019, dimana waktu penelitian mengacu pada kalender akademik yang ada di sekolah, karena PTK memerlukan beberapa siklus yang membutuhkan proses belajar mengajar secara efektif dan efisien. Teknik pengumpulan data dapat dilakukan dengan menggunakan teknik tes dan non tes.

Teknik tes yang dilakukan dalam penelitian ini adalah dengan memberikan tes awal pada siklus I dilakukan kepada siswa setelah materi diajarkan atau tes pada kegiatan akhir pelajaran dengan tujuan untuk mengetahui seberapa besar tingkat pemahaman siswa terhadap materi yang sudah diajarkan oleh peneliti.

Teknik non tes yang dilakukan dalam penelitian ini adalah:observasi, dokumentasi dan wawancara. Observasi bertujuan untuk mengamati kekurangan atau kelemahan yang terjadi selama proses pembelajaran yang berhubungan dengan kondisi interaksi belajar mengajar, tingkah laku, dan interaksi kelompok. Oservasi juga digunakan untuk mengobservasi pelaksanaan tindakan yang dilakukan oleh peneliti dalam rangka kegiatan pembelajaran. Dalam kegiatan ini peneliti mencatat kejadian-kejadian yang muncul dalam proses pembelajaran. Teknik observasi dilakukan untuk memperoleh data tentang keaktifan siswa, respon siswa dan hambatanhambatan dalam proses pembelajaran.

Wawancara dilakukan peneliti terhadap guru kelas untuk mengetahui tingkat kemampuan dan pemahaman siswa pada mata pelajaran matematika dengan metode yang diterapkan guru di kelas.

Dokumentasi dilakukan di ruangan kelas pada saat demonstrasi berlangsung sebagai bukti bahwa demonstrasi telah diadakan di ruangan kelas bersama siswa. Dokumentasi sebagai pelengkap penelitian.

Untuk mengetahui keaktifan suatu model dalam kegiatan pembelajaran, perlu dilakukan analisis data. Pada Penelitian Tindakan Kelas digunakan analisis deskripsi kualitatif, yaitu suatu metode penelitian yang bersifat menggambarkan kenyataan atau fakta sesuai dengan data yang diperoleh dengan tujuan untuk mengetahui hasil belajar yang dicapai dan untuk memperoleh respon siswa terhadap kegiatan pembelajaran serta aktivitas siswa selama proses pembelajaran (Wijaya, 2011: 191).

Untuk analisis tingkat keberhasilan atau persentase ketuntasan belajar siswa setelah proses belajar mengajar berlangsung pada setiap siklusnya, dilakukan dengan cara memberikan evaluasi tertulis pada setiap akhir siklus.

\section{HASIL DAN PEMBAHASAN \\ A. Hasil Penelitian \\ 1. Deskripsi Awal Pembelajaran Sebelum Tindakan}

Sebelum melaksanakan Penelitian tindakan Kelas (PTK) dengan menerapkan model pembelajaran kooperatif tipe STAD maka peneliti melakukan observasi. Observasi dan wawancara yang dilakukan oleh peneliti pada hari Senin, 20 Mei 2019. Berdasarkan hasil observasi bahwa proses pembelajaran Matematika yang berlangsung di SDI Blidit masih didominasi oleh guru. Walaupun guru memberikan kesempatan dan terus mendorong siswa, siswa kurang antusias dalam proses pembelajaran dan tidak berani dalam mengajukan pertanyaan dan juga siswa kurang mampu dalam mengemukakan pendapat serta belum serius dalam mengerjakan tugas. Hal 
Theresia Anisensia, Gregorius Sebo Bito dan Marselina Wali

Penerapan Model Pembelajaran Kooperatif Tipe STAD untuk Meningkatkan Hasil Belajar Matematika pada Siswa Kelas V SDI Blidit Kabupaten Sikka

PRIMA MAGISTRA: Jurnal Ilmiah Kependidikan Nomor 1, Volume 1, April 2020, hal 61-69

inilah yang menyebabkan proses pembelajaran menjadi tidak efektif sehingga mempengaruhi hasil belajar siswa kelas V pada pelajaran Matematika.

Dari hasil observasi yang dilakukan peneliti, maka peneliti menindak lanjuti dengan menggunakan Model Pembelajaran kooperatif tipe STAD dalam pembelajaran Matematika. Sebelum melaksanakan tindakan, peneliti melakukan kegiatan awal yaitu dengan melakukan Pre-test.

Pre-test yang dibuat peneliti bertujuan untuk mengetahui kemampuan awal siswa dalam mata pelajaran Matematika sebelum menggunakan Model pembelajaran kooperatif Tipe STAD. Pelaksanaan tes awal terhadap siswa pada pembelajaran Matematika dengan materi pengolahan data dilaksanakan pada tanggal 27 Mei 2019 dengan jumlah butir soal yang digunakan dalam pre test ini sebanyak 5 butir soal dengan bentuk soal isian.

Hasil pre-test menunjukkan bahwa jumlah siswa yang memperoleh nilai di atas KKM sebanyak 2 orang dengan nilai rata-rata keseluruhan 51,18 dan persentase ketuntasan $51,18 \%$. Berdasarkan hasil analisis maka peneliti terdorong untuk menerapkan model pembelajaran kooperatif tipe STAD.

\section{Deskripsi Hasil Pelaksanaan Tindakan Pada Siklus I}

a) Data Aktivitas Guru.

Aktivitas guru dinilai mulai dari kegiatan guru dalam mempersiapkan perangkat pembelajaran sampai dengan aktivitas guru saat proses pembelajaran yang diterapkan dengan penggunaan model pembelajaran kooperatif tipe STAD.

Kemampuan guru dalam mengelolah pembelajaran di amati oleh dua orang pengamat. Kategori skor pengamatan terdiri dari 5 skor yaitu: $5=$ sangat baik, $4=$ baik, $3=$ cukup baik, 2 =kurang, $1=$ sangat kurang.

Berdasarkan data yang diperoleh diketahui bahwa hal-hal yang masuk dalam kategori kurang yaitu : melakukan apersepsi dan motivasi siswa belajar, kemampuan dalam menguasai materi, kemampuan membimbing kelompok dalam mengalami kesulitan, kemampuan mengaktifkan siswa kelompok lain dalam menanggapi hasil diskusi.
Sedangkan hal-hal yang masih cukup yaitu: menyampaikan tujuan pembelajaran, menyampaikan materi pokok, membagi siswa dalam bentuk kelompok dan membagi LKS, kemampuan membimbing siswa dalam menyampaikan hasil diskusi, menuntun siswa untuk memberikan jawaban yang benar dan tepat, menyimpulkan materi

Berdasarkan penjelasan di atas dapat diketahui bahwa aktivitas guru selama proses pembelajaran berlangsung pada siklus I yaitu tingkat keberhasilan aktivitas guru dilihat dari rata-rata keseluruhan 2,80 dengan persentasi $56,15 \%$. Hal ini menunjukan bahwa aktivitas guru dikategorikan kurang maksimal dan perlu di tingkatkan pada siklus berikutnya.

b) Data Aktivitas Siswa

Selama proses belajar mengajar berlangsung peneliti mengamati aktivitas siswa dinilai mulai dari persiapan yang dilakukan sebelum mengikuti pembelajaran sampai dengan kegiatan siswa saat pembelajaran berlangsung seperti perhatian terhadap materi pembelajaran, semangat mengikuti pembelajaran, aktif dalam bertanya, menyampaikan pendapat dan aktif dalam kelompok saat mengerjakan LKS.

Berdasarkan data yang diperoleh bahwa hal-hal yang masih kurang yaitu: kemampuan membentuk kelompok sesuai arahan guru dan mengerjakan LKS yang diberikan, kemampuan siswa dalam mengidentifikasi penyelesaian masalah yang disajikan dalam LKS, kemampuan siswa dalam bertanya tentang pertanyaan yang belum dipahami dalam LKS, kemampuan dalam menyimak dan memahami penjelasan guru tentang jawaban-jawaban yang benar.

Sedangkan hal-hal yang cukup yaitu: kemampuan siswa dalam menyimak penjelasan guru tentang materi yang akan diajarkan, kemampuan siswa dalam memahami penjelasan guru tentang materi yang diajarkan, kemampuan siswa dalam menyelesaikan soal pada LKS, kemampuan siswa dalam mempresentasikan hasil diskusi, kemampuan dalam menyelesaikan soal evaluasi.

Berdasarkan penjelasan di atas dapat diketahui bahwa aktivitas siswa selama proses pembelajaran berlangsung pada siklus I yaitu tingkat keberhasilan di lihat dari rata-rata 2,5 
Theresia Anisensia, Gregorius Sebo Bito dan Marselina Wali

Penerapan Model Pembelajaran Kooperatif Tipe STAD untuk Meningkatkan Hasil Belajar Matematika pada Siswa Kelas V SDI Blidit Kabupaten Sikka

PRIMA MAGISTRA: Jurnal Ilmiah Kependidikan Nomor 1, Volume 1, April 2020, hal 61-69

dengan persentasi 50\%. Hal ini menunjukan bahwa aktivitas siswa masih kurang dan perlu ditingkatkan pada siklus berikutnya.

c) Hasil Belajar Peserta Didik Siklus I

Setelah diterapkannya pembelajaran kooperatif tipe STAD pada materi pengolahan data melalui evaluasi yang telah diberikan pada Siklus I dan untuk mengetahui sejauh mana siswa telah menguasai materi pelajaran.

Berdasarkan data yang diperoleh dapat disimpulkan bahwa hasil nilai tes siswa $60,5 \%$ dapat dikatakan belum tuntas karena belum mencapai $\mathrm{KKM} \geq 65 \%$ ketuntasan pada siklus I sehingga perlu ditingkatkan pada siklus berikutnya.

\section{d) Observasi Kelompok}

Pengamatan dilaksanakan bersamaan dengan pelaksanaan belajar mengajar. Selama kegiatan belajar mengajar berlangsung siswa dibagi dalam 4 kelompok yang terdiri dari 5 orang yang dibagi secara heterogen kemudian siswa menyelesaikan LKS dengan tujuan untuk mengukur kemampuan cara belajar siswa aktif dan untuk mengetahui kemampuan siswa dalam proses belajar mengajar dengan menggunakan model STAD. Tingkat keaktifan siswa selama mengikuti pembelajaran berdasarkan hasil observasi pada siklus I dapat disajikan pada Tabel 1 berikut.

Tabel 1

Nilai Perolehan Skor Perkembangan Siklus I

\begin{tabular}{|c|c|c|c|c|}
\hline \multirow{2}{*}{$\begin{array}{c}\text { Nama } \\
\text { Kelomp } \\
\text { ok } \\
\end{array}$} & \multirow[b]{2}{*}{ Kode Siswa } & \multicolumn{3}{|c|}{ Skor } \\
\hline & & $\begin{array}{l}\text { Pre } \\
\text { test }\end{array}$ & $\begin{array}{c}\text { Post } \\
\text { test }\end{array}$ & $\begin{array}{c}\text { Perkembang } \\
\text { an }\end{array}$ \\
\hline \multirow{8}{*}{ Melati } & $\mathrm{AR}$ & 90 & 100 & 30 poin \\
\hline & AS & 47 & 60 & 20 poin \\
\hline & BBS & 60 & 40 & 0 poin \\
\hline & FNM & 47 & 70 & 20 poin \\
\hline & LNL & 63,3 & 100 & 30 poin \\
\hline & Skor Total Tim & \multicolumn{3}{|c|}{100} \\
\hline & Rata-Rata Tim & \multicolumn{3}{|c|}{20} \\
\hline & Penghargaan Tim & \multicolumn{3}{|c|}{ TIM HEBAT } \\
\hline \multirow{8}{*}{ Mawar } & $\mathrm{MCO}$ & 57 & 80 & 30 \\
\hline & $\mathrm{MN}$ & 57 & 50 & 10 \\
\hline & MAH & 40 & 40 & 10 \\
\hline & MNS & 60 & 60 & 10 \\
\hline & MO & 17 & 50 & 30 \\
\hline & Skor Total Tim & \multicolumn{3}{|c|}{80} \\
\hline & Rata-Rata Tim & \multicolumn{3}{|c|}{16} \\
\hline & Penghargaan Tim & \multicolumn{3}{|c|}{ TIM BAIK } \\
\hline \multirow{4}{*}{ Anggrek } & MK & 47 & 60 & 20 \\
\hline & NL & 50 & 50 & 10 \\
\hline & ONS & 40 & 70 & 30 \\
\hline & OS & 40 & 40 & 10 \\
\hline
\end{tabular}

\begin{tabular}{|c|c|c|c|c|}
\hline & $\begin{array}{c}\text { PSA } \\
\text { Skor Total Tim } \\
\text { Rata-Rata Tim } \\
\text { Penghargaan Tim }\end{array}$ & 40 & 50 & 20 \\
\hline & MK & 37 & 60 & 30 \\
\hline & NL & 57 & 70 & 20 \\
\hline & ONS & 80 & 50 & 0 \\
\hline Matahar & OS & 57 & 60 & 20 \\
\hline i & PSA & 40 & 50 & 20 \\
\hline & Skor Total Tim & \multicolumn{3}{|c|}{90} \\
\hline & Rata-Rata Tim & \multicolumn{3}{|c|}{18} \\
\hline & Penghargaan Tim & \multicolumn{3}{|c|}{ TIM BAIK } \\
\hline
\end{tabular}

Berdasarkan tabel hasil LKS diatas masing-masing tim mendapatkan penghargaan /predikat "Tim Hebat" dan "Tim Baik" dengan rata-rata tim tertinggi 20 dan terendah 16 dan masing-masing kelompok mendapat penghargaan atau hadiah.

e) Refleksi

Berdasarkan hasil observasi aktivitas guru dan siswa yang dilaksanakan pada siklus I diperoleh rata-rata aktivitas guru yaitu 2,80 dengan persentasi $56,15 \%$ dan aktivitas Siswa 25 dengan presentasi 50\%. Dari data tersebut aktivitas guru dan peserta didik pada siklus I dengan kategori kurang dan data hasil tes siswa siklus I diperoleh presentasi ketuntasan 60,5\%. Dapat dikatakan bahwa hasil tes tersebut belum memenuhi KKM sehingga peneliti terdorong untuk memperbaiki tingkat hasil belajar Siswa pada pembelajaran selanjutnya yaitu pada siklus II.

\section{Deskripsi Hasil Pelaksanaan Tindakan Pada Siklus II}

Berdasarkan hasil analisis pada siklus I maka peneliti terdorong untuk menerapkan model pembelajaran kooperatif tipe STAD Pada siklus II yang dirincikan atas data tes dan data non tes. Data tes berupa tes hasil belajar Siswa dan data non tes berupa observasi aktivitas guru dan observasi aktivitas belajar siswa. Pada siklus II ini akan dipaparkan hasil penelitian dan interpretasi yaitu bagaimana menganalisis deskriptif kualitatif. Penyajian data hasil penelitian yang akan di uraikan adalah sebagai berikut :

\section{a. Data Aktivitas Guru} \begin{tabular}{rcrrr}
\multicolumn{2}{c}{ Berdasarkan } & data hasil & observasi \\
aktivitas guru & menunjukan & bahwa
\end{tabular} keterampilan guru pada siklus II mengalami peningkatan yaitu memiliki rata-rata 4,23 dengan presentasi $84,61 \%$. Hal ini menunjukan 
Theresia Anisensia, Gregorius Sebo Bito dan Marselina Wali

Penerapan Model Pembelajaran Kooperatif Tipe STAD untuk Meningkatkan Hasil Belajar Matematika pada Siswa Kelas V SDI Blidit Kabupaten Sikka

PRIMA MAGISTRA: Jurnal Ilmiah Kependidikan Nomor 1, Volume 1, April 2020, hal 61-69

bahwa aktivitas guru dikategorikan sangat baik, maka siklus berikutnya tidak perlu dilanjutkan lagi.

\section{b. Data Aktivitas Peserta Didik}

Berdasarkan data yang diperoleh, dapat diketahui bahwa aktivitas peserta didik selama proses pembelajaran berlangsung pada siklus II mendapat nilai rata-rata 4,38 dengan presentasi $87,7 \%$. Hal ini menunjukan bahwa aktivitas siswa sudah sangat baik, maka siklus berikutnya tidak perlu dilanjutkan lagi.

\section{c. Hasil Belajar Siswa Siklus II}

Berdasarkan data hasil evaluasi siklus II di atas dari 20 orang peserta didik yang mencapai KKM berjumlah 20 orang dengan rata-rata 86 dan presentasi ketuntasan $86 \%$, dengan nilai tertinggi 100 dan terendah 70 .

\section{d. Observasi Kelompok STAD}

Pengamatan dilaksanakan bersamaan dengan pelaksanaan belajar mengajar. Selama kegiatan belajar mengajar berlangsung siswa dibagi dalam 4 kelompok yang terdiri dari 5 orang yang dibagi secara heterogen kemudian siswa menyelesaikan LKS dengan tujuan untuk mengukur kemampuan cara belajar siswa aktif dan untuk mengetahui kemampuan siswa dalam proses belajar mengajar dengan menggunakan model STAD.

Tabel 2.

Nilai Perolehan Skor Perkembangan Siklus II

\begin{tabular}{|c|c|c|c|c|}
\hline \multirow{2}{*}{$\underset{\text { kelompok }}{\text { Nama }}$} & \multirow{2}{*}{$\begin{array}{l}\text { Kode } \\
\text { Siswa }\end{array}$} & \multicolumn{3}{|c|}{ Skor } \\
\hline & & $\begin{array}{l}\text { Pre } \\
\text { test }\end{array}$ & $\begin{array}{r}\text { Post } \\
\text { test }\end{array}$ & $\begin{array}{c}\text { Perkembanga } \\
\mathbf{n}\end{array}$ \\
\hline \multirow{8}{*}{ Melati } & $\mathrm{AR}$ & 90 & 100 & 30 \\
\hline & AS & 47 & 80 & 30 \\
\hline & BBS & 60 & 90 & 30 \\
\hline & FNM & 47 & 80 & 30 \\
\hline & LNL & 63,3 & 100 & 30 \\
\hline & $\begin{array}{l}\text { Skor } \\
\text { Total Tim }\end{array}$ & \multicolumn{3}{|c|}{150} \\
\hline & $\begin{array}{l}\text { Rata-Rata } \\
\text { Tim }\end{array}$ & \multicolumn{3}{|c|}{30} \\
\hline & $\begin{array}{l}\text { Pengharg } \\
\text { aan Tim }\end{array}$ & \multicolumn{3}{|c|}{ TIM SUPER } \\
\hline \multirow{8}{*}{ Mawar } & $\mathrm{MCO}$ & 57 & 100 & 30 \\
\hline & MN & 57 & 90 & 30 \\
\hline & MAH & 40 & 100 & 30 \\
\hline & MNS & 60 & 80 & 20 \\
\hline & $\mathrm{MO}$ & 17 & 80 & 30 \\
\hline & $\begin{array}{l}\text { Skor } \\
\text { Total Tim }\end{array}$ & \multicolumn{3}{|c|}{140} \\
\hline & $\begin{array}{l}\text { Rata-Rata } \\
\text { Tim }\end{array}$ & \multicolumn{3}{|c|}{28} \\
\hline & $\begin{array}{l}\text { Pengharg } \\
\text { aan Tim }\end{array}$ & \multicolumn{3}{|c|}{ TIM SUPER } \\
\hline
\end{tabular}

\begin{tabular}{|c|c|c|c|c|}
\hline \multirow{8}{*}{ Anggrek } & MK & 47 & 90 & 30 \\
\hline & NL & 50 & 90 & 30 \\
\hline & ONS & 40 & 80 & 30 \\
\hline & OS & 40 & 80 & 30 \\
\hline & PSA & 40 & 80 & 30 \\
\hline & $\begin{array}{l}\text { Skor } \\
\text { Total Tim }\end{array}$ & \multicolumn{3}{|c|}{150} \\
\hline & $\begin{array}{c}\text { Rata-Rata } \\
\text { Tim }\end{array}$ & \multicolumn{3}{|c|}{30} \\
\hline & $\begin{array}{c}\text { Pengharg } \\
\text { aan Tim }\end{array}$ & \multicolumn{3}{|c|}{ TIM SUPER } \\
\hline \multirow{8}{*}{ Matahari } & MK & 37 & 80 & 30 \\
\hline & NL & 57 & 90 & 30 \\
\hline & ONS & 80 & 70 & 10 \\
\hline & $\mathrm{OS}$ & 57 & 90 & 30 \\
\hline & PSA & 40 & 70 & 30 \\
\hline & $\begin{array}{c}\text { Skor } \\
\text { Total Tim }\end{array}$ & \multicolumn{3}{|c|}{130} \\
\hline & $\begin{array}{c}\text { Rata-Rata } \\
\text { Tim }\end{array}$ & \multicolumn{3}{|c|}{26} \\
\hline & $\begin{array}{c}\text { Pengharg } \\
\text { aan Tim }\end{array}$ & \multicolumn{3}{|c|}{ TIM SUPER } \\
\hline
\end{tabular}

Berdasarkan tabel hasil LKS di atas masing-masing tim mendapatkan penghargaan /predikat "Tim Super" dengan rata-rata tim tertinggi 30 dan terendah 26 dan masingmasing kelompok mendapat penghargaan atau hadiah.

e. Refleksi

Berdasarkan data di atas dapat diketahui bahwa nilai rata-rata siswa pada siklus II setelah menerapkan model pembelajaran kooperatif tipe STAD adalah $86 \%$. Dengan nilai tertinggi yang diperoleh siswa adalah 100 dan yang terendah adalah 70 . Maka dapat disimpulkan untuk siklus II diperoleh hasil belajar siswa dengan tingkat penguasaan siswa terhadap materi tergolong sangat baik karena presentasi ketuntasan meningkat. Dengan demikian penelitian ini tidak dilanjutkan ke siklus berikutnya.

\section{Rangkuman}

a. Rangkuman Aktivitas Guru Siklus I dan II

Berdasarkan data yang diperoleh dapat disimpulkan bahwa aktivitas guru sudah mengalami peningkatan dari rata-rata siklus I yaitu 2,80 menjadi 4,23 dengan persentasi $70,38 \%$. Hal tersebut menunjukan bahwa aktivitas guru siklus I ke siklus II mengalami peningkatan dan di kategorikan baik.

b. Rangkuman Aktivitas Siswa Siklus I dan II Berdasarkan data yang dihasilkan dapat diketahui bahwa perkembangan aktivitas siswa pada siklus I ke siklus II mengalami peningkatan dari rata-rata siklus I 2,5 menjadi 
Theresia Anisensia, Gregorius Sebo Bito dan Marselina Wali

Penerapan Model Pembelajaran Kooperatif Tipe STAD untuk Meningkatkan Hasil Belajar Matematika pada Siswa Kelas V SDI Blidit Kabupaten Sikka

PRIMA MAGISTRA: Jurnal Ilmiah Kependidikan Nomor 1, Volume 1, April 2020, hal 61-69

4,38 dengan nilai persentasi 68,8\%. Hal tersebut menunjukan bahwa aktivitas guru dari siklus I ke siklus II mengalami peningkatan dengan kategori cukup baik.

\section{c. Hasil Belajar siswa Siklus I dan II}

Berdasarkan data yang diperoleh maka perbandingan hasil evaluasi siswa siklus I dan siklus II sudah mengalami peningkatan dari rata-rata siklus I 60,5 menjadi 86 dengan persentasi $73,5 \%$.

d. Rangkuman Nilai Perkembangan Individu Dan Kelompok

Tabel 3

Nilai Perkembangan Individu dan Kelompok

\begin{tabular}{|c|c|c|c|c|c|}
\hline \multirow{2}{*}{$\begin{array}{c}\text { Nama } \\
\text { kelomp } \\
\text { ok }\end{array}$} & \multirow[b]{2}{*}{$\begin{array}{l}\text { Kode } \\
\text { Siswa }\end{array}$} & \multicolumn{4}{|c|}{ Skor } \\
\hline & & $\begin{array}{l}\text { Pre } \\
\text { test }\end{array}$ & $\begin{array}{c}\text { Siklu } \\
\text { S I }\end{array}$ & & $\begin{array}{l}\text { Perkem } \\
\text { bangan }\end{array}$ \\
\hline \multirow{8}{*}{ Melati } & AR & 90 & 100 & & 30 \\
\hline & AS & 47 & 60 & & 30 \\
\hline & BBS & 60 & 40 & & 30 \\
\hline & FNM & 47 & 70 & & 40 \\
\hline & LNL & 63,3 & 100 & & 30 \\
\hline & $\begin{array}{l}\text { Skor Total } \\
\text { Tim }\end{array}$ & \multicolumn{4}{|c|}{150} \\
\hline & $\begin{array}{l}\text { Rata-Rata } \\
\text { Tim }\end{array}$ & \multicolumn{4}{|c|}{30} \\
\hline & $\begin{array}{c}\text { Pengharga } \\
\text { an Tim }\end{array}$ & \multicolumn{4}{|c|}{ TIM SUPER } \\
\hline \multirow{8}{*}{ Mawar } & $\mathrm{MCO}$ & 57 & 80 & 100 & 30 \\
\hline & MN & 57 & 50 & 90 & 30 \\
\hline & MAH & 40 & 40 & 100 & 30 \\
\hline & MNS & 60 & 60 & 80 & 20 \\
\hline & MO & 17 & 50 & 80 & 30 \\
\hline & $\begin{array}{c}\text { Skor Total } \\
\text { Tim }\end{array}$ & \multicolumn{4}{|c|}{140} \\
\hline & $\begin{array}{c}\text { Rata-Rata } \\
\text { Tim }\end{array}$ & \multicolumn{4}{|c|}{28} \\
\hline & $\begin{array}{c}\text { Pengharga } \\
\text { an Tim }\end{array}$ & \multicolumn{4}{|c|}{ TIM SUPER } \\
\hline \multirow{8}{*}{$\begin{array}{c}\text { Anggre } \\
\mathbf{k}\end{array}$} & MK & 47 & 60 & 90 & 30 \\
\hline & $\mathrm{NL}$ & 50 & 50 & 90 & 30 \\
\hline & ONS & 40 & 70 & 80 & 20 \\
\hline & $\mathrm{OS}$ & 40 & 40 & 80 & 30 \\
\hline & PSA & 40 & 50 & 80 & 30 \\
\hline & $\begin{array}{c}\text { Skor Total } \\
\text { Tim }\end{array}$ & \multicolumn{4}{|c|}{140} \\
\hline & $\begin{array}{c}\text { Rata-Rata } \\
\text { Tim }\end{array}$ & \multicolumn{4}{|c|}{28} \\
\hline & $\begin{array}{c}\text { Pengharga } \\
\text { an Tim }\end{array}$ & \multicolumn{4}{|c|}{ TIM SUPER } \\
\hline \multirow{8}{*}{$\begin{array}{l}\text { Mataha } \\
\text { ri }\end{array}$} & MK & 37 & 60 & 80 & 30 \\
\hline & NL & 57 & 70 & 90 & 30 \\
\hline & ONS & 80 & 50 & 70 & 10 \\
\hline & $\mathrm{OS}$ & 57 & 60 & 90 & 30 \\
\hline & PSA & 40 & 50 & 70 & 30 \\
\hline & $\begin{array}{c}\text { Skor Total } \\
\text { Tim }\end{array}$ & \multicolumn{4}{|c|}{130} \\
\hline & $\begin{array}{c}\text { Rata-Rata } \\
\text { Tim }\end{array}$ & \multicolumn{4}{|c|}{26} \\
\hline & $\begin{array}{c}\text { Pengharga } \\
\text { an Tim }\end{array}$ & \multicolumn{4}{|c|}{ TIM SUPER } \\
\hline
\end{tabular}

Dari tabel di atas semua kelompok memperoleh penghargaan tim super. Dengan perolehan rata-rata masing-masing kelompok yaitu kelompok melati 30, kelompok mawar 28, kelompok anggrek 28, dan kelompok matahari 26.

\section{B. Pembahasan}

Berdasarkan hasil penelitian sebelum penerapan Model pembelajaran kooperatif tipe STAD menunjukan bahwa dalam proses belajar mengajar siswa maupun Guru kurang aktif, terjadi banyak permasalahan di dalam kelas antara lain: antara siswa saling mengganggu, siswa sering keluar masuk kelas, guru kurang mendampingi siswa dalam berdiskusi kelompok. Siswapun belum mengenal model pembelajaran kooperatif tipe STAD. Hal ini dapat dilihat dari hasil nilai pre test yang sebelum diberikan tindakan yang mencapai 51,18, yang terdiri dari 20 siswa yang mencapai ketuntasan 2 siswa dengan KKM 65 yang telah ditetapkan di sekolah SDI Blidit. Hal ini menunjukan bahwa hasil belajar siswa masih sangat rendah. Oleh karena itu, peneliti menerapkan model pembelajaran kooperatif tipe STAD dalam pembelajaran sehingga siswa dapat diarahkan.

Dilihat dari peningkatan hasil belajar siswa, sebelum menggunakan Model pembelajaran kooperatif tipe STAD hasil belajar siswa sangat menurun. Setelah menggunakan Model pembelajaran kooperatif tipe STAD dan dengan berbagai tahap pelaksanaan yang diterapkan diketahui bahwa hasil belajar siswa pada mata pelajaran Matematika mengalami peningkatan yang sangat baik yang ditinjau dari pre test, Siklus I dan Siklus II.

a. Pembahasan hasil observasi aktivitas Guru dan hasil aktivitas belajar siswa

Rekapitulasi rata-rata skor hasil analisis aktivitas Guru pada siklus I sebesar $56,15 \%$ dan siklus II sebesar 84,61\%. Dan rekapitulasi hasil analisis aktivitas belajar Siswa pada siklus I sebesar $50 \%$ dan siklus II sebesar $87,7 \%$. Berdasarkan penjelasan tersebut bahwa terjadi peningkatan persentasi aktivitas guru dan aktivitas belajar siswa dalam mengikuti pembelajaran matematika dengan 
Theresia Anisensia, Gregorius Sebo Bito dan Marselina Wali

Penerapan Model Pembelajaran Kooperatif Tipe STAD untuk Meningkatkan Hasil Belajar Matematika pada Siswa Kelas V SDI Blidit Kabupaten Sikka

PRIMA MAGISTRA: Jurnal Ilmiah Kependidikan Nomor 1, Volume 1, April 2020, hal 61-69

menggunakan model pembelajaran kooperatif tipe STAD.

Hasil observasi pada siklus I menunjukan bahwa kurang adanya kerja sama antara siswa yang satu dengan yang lainnya masih bersifat individu serta siswa lebih banyak bermain. Dan guru mengalami peningkatan kemampuan dalam melaksanakan pembelajaran dengan menggunakan Model kooperatif tipe STAD. Berdasarkan hasil di atas persentasi aktivitas guru dan siswa pada pembelajaran matematika dengan materi pengolahan data pada siklus I dan II dengan penerapan model pembelajaran kooperatif tipe STAD mengalami peningkatan.

\section{b. Pembahasan Hasil Belajar Siswa}

Berdasarkan hasil tes dan aktivitas belajar siswa baik secara individu maupun kelompok dalam proses pembelajaran, dimana tes hasil belajar pada siklus I memperoleh nilai rata-rata 60,5, setelah diadakan siklus II ketuntasan belajar siswa meningkat yaitu 86 . Hasil observasi aktivitas belajar siswa secara individu maupun kelompok pada siklus I berada pada kategori cukup baik. Setelah diadakan tindakan pada siklus II terjadi peningkatan yaitu dikategorikan sangat baik.

Pada siklus I rata-rata nilai siswa mencapai 60,5 sedangkan ketuntasan belajar siswa mencapai 6 orang atau 30\%. Pada siklus II rata-rata nilai siswa mencapai 86 dengan ketuntasan mencapai 20 orang siswa atau $100 \%$ dengan kata lain semuanya telah mencapai ketuntasan dalam pembelajaran.

Dalam model pembelajaran kooperatif tipe STAD siswa memiliki kesempatan untuk mengemukakan pendapat dan mencari tau informasi yang didapat dan dapat meningkatkan keterampilan berkomunikasi. Anggota kelompok bertanggung jawab terhadap keberhasilan kelompoknya dan dapat menyampaikan informasinya kepada kelompok lain.

Dari hasil kegiatan pembelajaran melalui perbaikan pembelajaran dengan tahapan persiklus dapat disimpulkan bahwa dengan menerapkan model pembelajaran kooperatif tipe STAD materi pengolahan data, siswa kelas V SDI Blidit memperoleh peningkatan hasil belajar atau berpengaruh positif.
Dalam proses perbaikan pada siklus II dengan rata-rata nilai mencapai 86 sedangkan hasil ketuntasan belajar siswa telah mencapai $100 \%$ dari hasil perbaikan tersebut dapat disimpulkan bahwa dengan menerapkan model pembelajaran kooperatif tipe STAD pada pelajaran matematika pada siswa kelas V SDI Blidit telah memenuhi kriteria ketuntasan belajar sehingga dapat meningkatkan hasil belajar siswa.

Maka Penggunaan Model pembelajaran kooperatif tipe STAD dari siklus I hingga Siklus II mengalami perkembangan yang signifikan. Untuk mendukung perkembangan perolehan hasil belajar pada Siklus I dan Siklus II dapat dilihat pada Tabel di bawah ini:

Tabel 4

Perbandingan rata-rata perkembangan nilai hasil belajar Siswa

\begin{tabular}{llcc} 
& \multicolumn{3}{c}{ hasil belajar Siswa } \\
\hline No & Kegiatan & $\begin{array}{c}\text { Nilai Test } \\
\text { Evaluasi }\end{array}$ & Perkembangan \\
\hline 1 & Pre-Test & $\begin{array}{c}51,18 \\
60,5\end{array}$ & 9,32 \\
& Siklus I & $\begin{array}{c}60,5 \\
86\end{array}$ & 25,5 \\
\hline 2 & Siklus I & S6 & \\
& Siklus II & 86
\end{tabular}

\section{KESIMPULAN DAN SARAN}

Berdasarkan hasil penelitian dan pembahasan yang dilakukan oleh peneliti setelah dilakukan pembelajaran dengan menerapkan model pembelajaran kooperatif tipe STAD maka disimpulkan bahwa:

1. Rancangan pembelajaran Matematika di kelas V SDI Blidit dengan menerapkan model pembelajaran kooperatif tipe STAD yang sudah diterapkan, di mana pelaksanaannya sesuai dengan prosedur yang sudah dirancangkan, sehingga dapat mempengaruhi peningkatan hasil belajar siswa. Dengan penerapan model pembelajaran kooperatif tipe STAD, siswa sangat berprestasi dalam kegiatan pembelajaran, sangat aktif dalam kelas dan dapat meningkatkan hasil belajar siswa.

2. Penerapan model pembelajaran kooperatif tipe STAD untuk peningkatan hasil belajar siswa kelas V SDI Blidit telah terlaksana dengan baik dan mengalami peningkatan dari siklus I ke Siklus II. Hasil belajar siswa kelas V SDI Blidit pada 
Theresia Anisensia, Gregorius Sebo Bito dan Marselina Wali

Penerapan Model Pembelajaran Kooperatif Tipe STAD untuk Meningkatkan Hasil Belajar Matematika pada Siswa Kelas V SDI Blidit Kabupaten Sikka

PRIMA MAGISTRA: Jurnal Ilmiah Kependidikan Nomor 1, Volume 1, April 2020, hal 61-69

pembelajaran Matematika materi pengolahan data mengalami peningkatan setelah menerapkan model pembelajaran kooperatif tipe STAD, dimana hasil yang diperoleh Pada siklus I dari 20 siswa yang mencapai KKM yaitu 6 orang dengan jumlah persentase ketuntasan $60,5 \%$, Sedangkan pada siklus II semua siswa sudah mencapai KKM dengan jumlah persentasi ketuntasan 86\%. Hasil belajar ini menunjukan bahwa adanya peningkatan hasil belajar dengan diterapkannya Model pembelajaran kooperatif tipe STAD pada pembelajaran Matematika materi pengolahan Data.

Berdasarkan penelitian yang telah dilakukan, untuk selanjutnya penulis ingin memberikan saran yang dapat membantu usaha meningkatkan hasil belajar siswa pada mata pelajaran Matematika. Saransaran yang dimaksud adalah sebagai berikut:

1. Bagi Guru

a. Hendaknya guru dapat memilih model pembelajaran yang tepat sehingga siswa dapat mencapai hasil yang maksimal sesuai harapan.

b. Guru dapat memperhatikan dan membantu siswa yang mengalami kesulitan dalam mengikuti pembelajaran.

c. Guru dapat memberikan dorongan kepada siswa yang kurang berminat dalam mempelajari matematika.

2. Bagi Siswa

a. Untuk meningkatkan hasil belajar, maka siswa mulai dilatih untuk melakukan pembelajaran kooperatif tipe STAD untuk menambah wawasan belajarnya.

b. Berusaha untuk belajar bersama temanteman ketika mengalami kesulitan.

c. Sebaliknya memanfaatkan waktu untuk bertanya kepada guru apabila masih mengalami kesulitan dalam kegiatan pembelajaran.

\section{DAFTAR PUSTAKA}

Desmita, 2012. Psikologi Perkembangan Peserta didik. Bandung: Remaja Rosdakarya

Hamzah, Ali, 2014. Perencanaan dan Strategi Pembelajaran Matematika. Jakarta: Raja Grafindo Persada

Mulyasa, E., 2011. Menjadi Guru Profesional. Bandung: PT. Remaja Rosdakarya

Muslich, Masnur, 2012. Melaksanakan PTK itu Mudah. Jakarta: Bumi Aksara

Muslich, Masnur, 2012. Perkembangan Peserta Didik. Jakarta: Bumi Aksara

Sani, A. Ridwan, 2014. Inovasi Pembelajaran. Jakarta: Bumi Aksara 